\title{
MANAJEMEN PENDIDIKAN ISLAM ANAK-ANAK PRA SEKOLAH BERBASIS QUR'ANI
}

\author{
Nurhadi \\ Sekolah Tinggi Agama Islam (STAI) Al-Azhar Pekanbaru Riau \\ alhadijurnal@gmail.com; alhadicentre@yahoo.co.id
}

\begin{abstract}
The pattern of educating children or the method of educating children from before birth to school age is a necessity for a mother. Mother is the first and main geographical teacher in pre-school children's education. The age of toddlers to pre-school for children is golden age. Learning while playing is a certainty, playing is the first education for children under five. The age of a toddler is like a blank cassette that can store and record something that is accustomed to and experienced in the development of a child's life. For parents, if they expect their children to become children who are good enough to have to have insight and knowledge of management of pre-school children's education. Among the many models and patterns of education management, the easiest way to deliver children to become good and noble children is quran-based management. Al-Qur'an is a boly book from the most holy God, it will be easily digested and accepted by the core of the teachings to children who are still pure. In terms of management of the pre-school education based on the Qur'an, it is intended for parents to plan for their children to always listen to the chants of the Qur'an. Then group them into playing the verses in the form of per juz al-Qur'an in one month. Then the parents evaluate the child who has been refreshed by the Qur'an, if the chanting is paused, what will happen to the child's reaction. If you cry, it means that the spirit of the Qur'an has entered your heart and soul. The situation is valid for 30 juz, so the child for 30 months has listened to and recorded 30 juz verses of the Qur'an, God willing, the age of pre-school children has been memorized and will be smart with the waslab verse of the Qur'an. This is a Qur'ani-based management that gives birth to children who love and love to read the Qur'an and the hafidz of the Qur'an.
\end{abstract}

Keywords: Management, Islamic Education, Children, Pre-School, Based Qur'ani

\begin{abstract}
Abstrak : Wanita Pola mendidik anak atau metode mendidik anak dari sebelum lahir sampai usia sekolah adalah keniscayaan bagi seorang ibu. Ibu adalah guru pertama dan geografis utama dalam pendidikan anak pra sekolah. Usia balita sampai pra sekolah bagi anak-anak adalah usia keemasan. Belajar sambil bermain suatu kepastian, kesenangan bermain merupakan pendidikan pertama anak balita. Usia balita bagaikan kaset kosong yang dapat menyimpan dan merekam sesuatu hal yang dibiasakan dan dialami dalam perkembangan kehidupan anak. Bagi orang tua, jika mengharapkan kelak anak-anaknya menjadi anak yang sholeh sholehah mesti memiliki wawasan dan pengetahuan manajemen pendidikan anak pra sekolah. Diantara sekian banyak model dan pola manajemen pendidikan, maka yang paling mudah untuk mengantarkan
\end{abstract}

Manazhim : Jurnal Manajemen dan Ilmu Pendidikan

Volume 1, Nomor 2, Agustus 2019; 12-25

https://ejournal.stitpn.ac.id/index.php/manazhim 
anak-anak menjadi anak yang baik dan berakhlak mulia adalah manajemen berbasis qur'ani. Al-Qur'an merupakan kitab suci dari Allah yang maha suci, maka akan mudah dicerna dan diterima inti ajarannya kepada anak-anak yang masih suci. Dalam hal manajemen pendidikan pra sekolah berbasis al-Qur'an, maka diperuntukkan kepada orang tua agar merencanakan untuk anaknya selalu mendengarkan lantunan ayat suci al-Qur'an. Kemudian mengelompokkan dalam memperdengarkan ayat-ayat tersebut dalam bentuk per juz al-Qur'an dalam satu bulan. Selanjutnya orang tua mengevaluasi anak yang sudah diperdegarkan al-Qur'an, jika diberhentikan sejenak lantunan tersebut, apa yang akan terjadi reaksi anak. Jika menangis, berarti ruh alQur'an sudah masuk dalam hati dan jiwanya. Keadaan tersebut berlaku sampai 30 juz, maka anak selama 30 bulan sudah mendengarkan dan merekam 30 juz ayat-ayat al-Qur'an, InsyaAllah umur pra sekolah anak sudah banyak hapal dan akan cerdas dengan wasilah ayat al-Qur'an. Inilah manajemen berbasis Qur'ani yang melahirkan anak-anak yang cinta dan gemar baca al-Qur'an serta hafidz al-Qur'an.

Kata Kunci: Manajemen, Pendidikan Islam, Anak, Pra Sekolah, Berbasis Qur'ani

\section{PENDAHULUAN}

Anak adalah buah hati orang tua, cahaya mata yang menyenangkan dan membahagiakan hati. Anak bak sesuatu yang sangat mahal dan berharga, mesti dijaga dan dipelihara agar selalu baik sampai akhirnya bisa berguna dan mendoakan orang tuanya di hari tua dan setelah di alam baqa. Anak usia dini merupakan masa emas yang sangat tepat untuk diberikan proses pendidikan awal. ${ }^{1}$ Pada masa ini anak usia dini mengalami proses pertumbuhan dan perkembangan secara signifikan. Anak belum menerima banyak pengaruh negatif dari lingkungannya. ${ }^{2}$ Orang tua ataupun pendidik akan lebih mudah mengarahkan pertumbuhan dan perkembangan anak dengan baik. Orang tualah yang memiliki andil terbesar pada masa emas (golden age) nya ini. ${ }^{3}$

Pendidikan pada anak usia pra sekolah merupakan upaya pembinaan yang ditujukan bagi anak sejak baru lahir sampai usia enam tahun, dengan cara memberikan rangsangan untuk membantu perkembangan dan pertumbuhan jasmani dan rohaninya, sehingga nantinya anak siap untuk mengikuti pendidikan formal, non formal dan informal. ${ }^{4}$

${ }^{1}$ Mansur. (2013). Pendidikan Anak Usia Dini dalam Islam. Yogyakarta: Pustaka Pelajar, hlm. 50. ${ }^{2}$ Mulyasa. (2016). Manajemen PAUD. Bandung: PT Remaja Rosdakarya, hlm. 47.

62.

${ }^{3}$ Fadhilah, Muhammad. (2015). Desain Pembelajaran Paud. Jogyakarta: Ar-Ruzz media, hlm. 61-

${ }^{4}$ Hasan, Maimunah. (2014). PAUD. Jakarta: Diva Press, hlm. 15. 
Ajaran Islam selalu mengajarkan agar supaya berpegang teguh pada Al-qur'an dan Al-hadit, karena Islam selalu bersumber dari dua sumber yang benar dan dapat dipercaya, sehingga cerita yang diberikan terjamin kebenaran dan keabsahannya di dalam al-Qur'an dan hadis. Pengaplikasian metode bercerita, mendengar dan diperdengarkan sangat sesuai dalam proses belajar mengajar anak usia pra sekolah. ${ }^{5}$ Metode bercerita, mendengar dan diperdengarkan merupakan metode pendidikan yang masyhur dan terbaik, sebab jika didasari oleh ketulusan hati yang mendalam, kisah itu mampu menyentuh jiwa. Metode ini telah terkenal sejak zaman dahulu pada masa para pujangga India, Persia dan Yunani. ${ }^{6}$

Hakikat pendidikan anak usia pra sekolah dilakukan bertujuan untuk memfasilitasi pertumbuhan dan perkembangan anak. Pada era modern ini, pendidikan merupakan sarana masyarakat untuk mencerdaskan generasi yang akan datang, beriman dan berakhlak mulia. Bahkan kemajuan bangsa dapat dilihat dari pola kemajuan di bidang pendidikan. ${ }^{7}$ Konsep pendidikan dalam pembelajaran ada di surah Al-'Alaq ayat ke 1-5), yaitu:

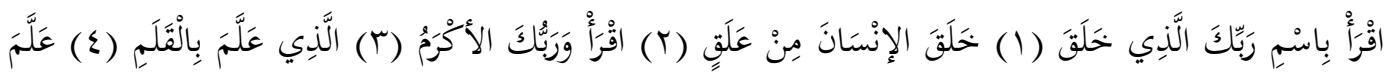

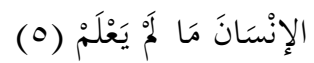

Artinya: Bacalah dengan (menyebut) nama Allah yang Menciptakan. Dia telah menciptakan manusia dari segumpal darah. Bacalah dan Allah yang Maha pemurah. Yang mengajar (manusia) dengan perantaran kalam. ${ }^{8}$ Dia mengajar kepada manusia apa yang tidak diketabuinya.

Dari lima ayat di atas dapat dipahami manajemen pendidikan anak yang paling efektif untuk usia balita pra sekolah membacakan atau memperdengarkan. Para pakar mengatakan, perkembangan intelektual anak hanya 80\% yang merupakan masa hlm. 170

${ }^{5}$ Moeslichatoen. (2014). Metode Pengajaran di Taman Kanak-kanak. Jakarta: PT Rineka Cipta, ${ }^{6}$ Arif, Armai. (2013). Pengantar Ilmu dan Metodologi Pendidikan Islam. Jakarta: Ciputat Pers, hlm. 160-161.

7Zulfitria. (2016). "Pembelajaran Tahfidz Al-Quran dalam Pendidikan Karakter Anak Usia Dini (Paud)". Darul Ilmi Jurnal Ilmiah Pendidikan Islam Anak Usia Dini Volume 1 No 2, 35-55, hlm. 36

${ }^{8}$ Maksudnya: Allah mengajar manusia dengan perantaraan tulis baca. 1079

${ }^{9}$ Departemen Agama RI. (2015). Al-Qur'an dan Terjemahanya. Semarang: Toha Putra, hlm. 
keemasan. ${ }^{10}$ Usia diantara 0-8 tahun mesti ada upaya yang mampu memfasilitasi anak pra sekolah dalam menumbuh kembangkan jiwa dan rohaninya. ${ }^{11}$

Undang-undang pendidikan nasional mengatakan bahwa anak usia pra sekolah memerlukan suatu upaya pembinaan dari sejak baru lahir sampai usia 6-8 tahun, dengan merangsangnya agar pertumbuhan dan perkembangannya memiliki kesiapan untuk pendidikan formal selanjutnya. Hal tersebut anak memerlukan kesiapan jasmani, rohani dan mental. ${ }^{12}$

Masa usia pra sekolah merupakan masa yang tepat untuk menanamkan dasardasar pendidikan karakter jiwa dan doktrin kebaikan kepada anak dalam pengembangan bahasa, fisik, sosial, emosional, seni, moral, konsep diri dan nilai-nilai agama. Orang tua selalu menekankan untuk sholat dan harus hafal bacaan sholat, setelah sholat harus berdoa dan juga wajib hafal doanya. Salah satu bacaan sholat yaitu dapat menghafal Juz amma atau menghafal Al-Qur'an (Tahfidz). ${ }^{13}$ Jika anak pra sekolah sudah banyak hafal al-Qur'an tanda jiwa sudah termenej oleh nilai-nilai alQur'an, diharapkan dapat menjiwai dan merasuk dalam hati instrumen wahyu alQur'an tersebut, sehingga dapat disebut dengan anak al-Qur'an berjalan.

Mendidik anak dengan pola pendidikan usia pra sekolah merupakan perkara yang sangat penting di dalam Islam, untuk membentuk dan mewujudkan generasi yang Qur'ani. Allah telah menceritakan bagaimana petuah Lukman dalam mendidik anak-anaknya. ${ }^{14}$ Petuah hikmah pendidikan yang diajarkan lukman berkaitan dengan pembentukan insan kamil sesuai tujuan pendidikan dalam ilmu filsafat pendidikan islam. Hal ini sangat sesuai dengan tujuan pendidikan dalam undang-undang sistem pendidikan nasional. Misalnya Allah menceritakan tentang mendidik anak versi Lukmanul hakim dalam al-Qur'an surah Luqman ayat 13-17 sebagai berikut:

${ }^{10}$ Dirjen Pendidikan Luar Sekolah Direktorat PAUD. (2015). Bekal Mendidik Anak Usia Dini. Jakarta: Dirjen pendidikan Luar Sekolah, hlm. 3-4

11Zulfitria. (2016). "Pembelajaran Tahfidz Al-Quran", hlm. 36

${ }^{12}$ Undang-undang Sisdiknas Nomor 20 Tahun 2003 pasal 1 ayat 14: Pendidikan anak usia dini adalah suatu upaya pembinaan yang ditujukan kepada anak sejak lahir sampai dengan usia enam tahun yang dilakukan melalui pemberian rangsangan pendidikan untuk membantu pertumbuhan dan perkembangan jasmani dan rohani agar anak memiliki kesiapan dalam memasuki pendidikan lebih lanjut. Lembaran Negara. (2003). Undang-undang Sistem pendidikan Nasional. Jakarta: Sisdiknas, 1-33, hlm. 4

13Zulfitria. (2016). "Pembelajaran Tahfidz Al-Quran", hlm. 37

${ }^{14}$ Ilham Senjari. (2017). "Tanggung Jawab Orangtua Terhadap Pendidikan Anak dalam Perspektif Hadist". Surakarta: Fakultas Ilmu Tarbiyah dan Keguruan Institut Agama Islam Negeri, hlm. 1 


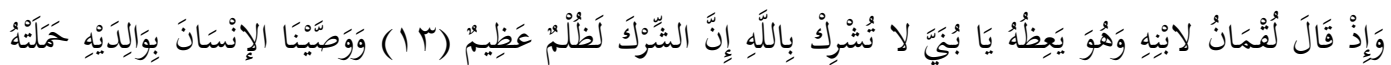

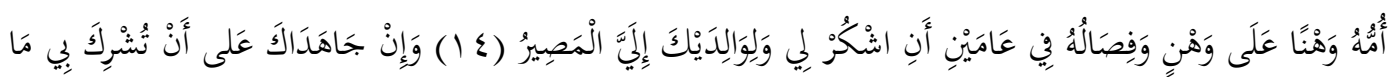

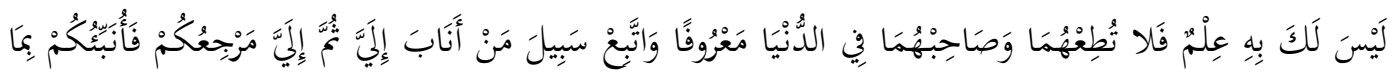

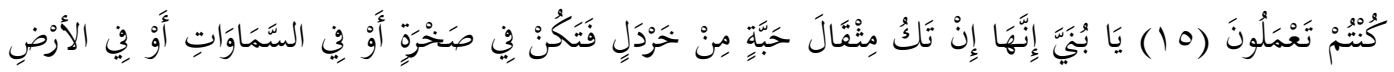

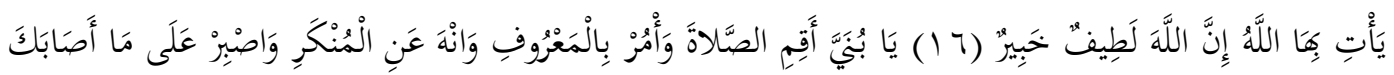

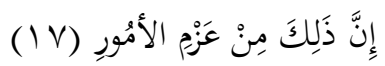

Artinya: Dan (ingatlah) ketika Luqman berkata kepada anaknya, di waktu ia memberi pelajaran kepadanya: "Hai anakku, janganlah kamu mempersekutukan Allah, Sesunggubnya mempersekutukan (Allah) adalab benar-benar kezaliman yang besar". Dan Kami perintabkan kepada manusia (berbuat baik) kepada dua orang ibu-bapanya; ibunya telah mengandungnya dalam Keadaan lemah yang bertambah-tambah, dan menyapibnya dalam dua tabun. ${ }^{15}$ bersyukurlah kepadaku dan kepada dua orang ibu bapakemu, banya kepada-Kulah kembalimu. Dan jikka keduanya memaksamu untuke mempersekutukan dengan aku sesuatu yang tidak ada pengetabuanmu tentang itu, Maka janganlah kamu mengikuti keduanya, dan pergaulilab keduanya di dunia dengan baik, dan ikutilah jalan orang yang kembali kepada-Ku, kemudian hanya kepada-Kulah kembalimu, Maka Kuberitakan kepadamu apa yang telah kamu kerjakan. Luqman berkata: "Hai anakku, Sesunggubnya jika ada (sesuatu perbuatan) seberat biji sawi, dan berada dalam batu atau di langit atau di dalam bumi, niscaya Allah akan mendatangkannya (membalasinya). Sesunggubnya Allab Maha Halus ${ }^{16}$ lagi Maha mengetabui. Hai anakku, dirikanlah shalat dan surublah (manusia) mengerjakan yang baik dan cegablab (mereka) dari perbuatan yang mungkar dan bersabarlah terbadap apa yang menimpa kamu. Sesungguhnya yang demikian itu Termasuk hal-hal yang diwajibkan (oleh Allah). ${ }^{17}$

Surah Lukman di atas sangat syarat dengan pendidikan anak, baik usia sekolah maupun pra sekolah, yang jelasnya yang pertama kali diajarkan adalah pendidikan Lukman tersebut adalah tentang iman, jiwa dan kandungan inti alQur'an.

Melalui latar belakang di atas, maka penulis hendak menjelaskan bagaimana manajemen pendidikan Islam anak-anak pra sekolah yang berbasis al-Qur'an?. Diharapkan dari artikel ini dapat diterapkan oleh para orang tua khususnya ibu

${ }^{15}$ Maksudnya: Selambat-lambat waktu menyapih ialah setelah anak berumur dua tahun.

${ }^{16}$ Yang dimaksud dengan Allah Maha Halus ialah ilmu Allah itu meliputi segala sesuatu bagaimana kecilnya.

${ }^{17}$ Departemen Agama RI. (2015). Al-Qur'an dan Terjemahanya, hlm. 654-655 
sebagai guru yang pertama mempraktekkannya, sehingga anak menjadi anak yang Qur'ani dalam pendidikan berikutnya.

\section{PEMBAHASAN}

\section{Hakikat Anak-anak dalam Islam}

Hakikat anak menurut Al-Qur'an disebut dengan berbagai macam bentuk, seperti zurriyah, ${ }^{18}$ ibn, $^{19}$ walad, $^{20}$ athfal, ${ }^{21}$ shabiy, ${ }^{22}$ aqrab, asbath, ${ }^{23}$ ghulam, ${ }^{24}$ thifl, ${ }^{25}$ nasl, ${ }^{26}$ rabaib, dan ad'iya'akum. ${ }^{27}$ Setiap istilah tersebut pada dasarnya mempunyai makna khusus secara sendiri, dan berbeda antara istilah yang satu dengan yang lainya. Zurriyah-nasl, term ini untuk menunjukkan suatu konsep anak dalam hal keturunan. Term ibn digunakan untuk istilah anak seayah seibu (anak kandung). Term waladathfal-shabiy-ghulam ungkapan ini lebih umum, yaitu anak-anak usia pra sekolah. Perbedaan makna tersebut merupakan bukti bahwa Al-Qur'an sangat peduli terhadap keberadaan anak sekaligus bagaimana pola pendidikan yang efektif diberlakukan. ${ }^{28}$

Sepanjang perjalanan hidup manusia usia anak-anak pra sekolah dan balita merupakan periode mendasar dalam proses pembelajaran dan pendidikan sebagai wujud menjaga pertumbuhan dan perkembangan anak. Keadaan ini sangat fundamental bagi anak usia pra sekolah sampai berakhir masa usia tersebut, periode ini disebut dengan perjalanan hidup manusia di masa keemasan dalam pendidikan anak. Teori ini cukup banyak untuk menguatkan fakta realita bahwa di usia ini potensi anak berkembang begitu pesat. Teori lain masa keemasan disebut juga dengan periode eksplorasi, periode peka dan masa bermain. Tapi ingat, bahwa masa

${ }^{18}$ Munawwir, Ahmad Warson. (1997). Kamus al-Munawwir. Surabaya: Pustaka Progresif, hlm. 444; lihat juga Abdul Baqi, Muhammad Fuad. (1980)). al-Mu'jam al-Mufahras li Alfaz. Al-Qur'an al-Karim. Beirut: Dar al- Fikr li at-Tiba'ah wa an-Nasyr wa at-Tauzu', hlm. 270-271

${ }^{19}$ Munawwir, Ahmad Warson. (1997). Kamus al-Munawwir, hlm. 112; lihat juga Abdul Baqi, Muhammad Fuad. (1980)). al-Mu'jam al-Mufahras, hlm. 270-271

${ }^{20}$ Abdul Baqi, Muhammad Fuad. (1980)). al-Mu'jam al-Mufahras, hlm. 270-271dan 763-765.

${ }^{21}$ Abdul Baqi, Muhammad Fuad. (1980)). al-Mu'jam al-Mufahras, hlm. 431

${ }^{22}$ Abdul Baqi, Muhammad Fuad. (1980)). al-Mu'jam al-Mufahras, hlm. 350

${ }^{23}$ Munawwir, Ahmad Warson. (1997). Kamus al-Munawwir, hlm. 605

${ }^{24}$ Abdul Baqi, Muhammad Fuad. (1980)). al-Mu'jam al-Mufahras, hlm. 505

${ }^{25}$ Abdul Baqi, Muhammad Fuad. (1980)). al-Mu'jam al-Mufahras, hlm. 431

${ }^{26}$ Abdul Baqi, Muhammad Fuad. (1980)). al-Mu'jam al-Mufahras, hlm. 699

${ }^{27}$ Munawwir, Ahmad Warson. (1997). Kamus al-Munawwir, hlm. 404; lihat juga Abdul Baqi, Muhammad Fuad. (1980)). al-Mu'jam al-Mufahras, hlm. 340

${ }^{28}$ Santi Awaliyah. (2008). "Konsep Anak dalam Al-Qur'an dan Implikasinya Terhadap Pendidikan Islam dalam Keluarga”. Jogjakarta: Fakultas Tarbiyah UIN Sunan Kalijaga, hlm. 103 
ini jika berlalu tidak mungkin terulang kembali, disebut juga masa kritis. Maka oleh sebab itu bagi orang tua, agar memaksimalkan pembinaan dalam mengembangkan pertumbuhan anak. Jika tidak terwujud hal tersebut pada anak, akan menghambat potensi anak pada masa usia sekolah sampai seterusnya. ${ }^{29}$

Anak lahir dalam keadaan fitrah, memiliki potensi yang juga berbeda-beda, hal ini bisa disebabkan faktor gen dan juga lingkungan, kemampuan orang tua dalam mengaktualisasikan potensi anak akan membuat fungi otak semakin maksimal. Fungsi utama otak manusia adalah interaksi genetika dan lingkungan. Pada saat manusia baru lahir, kelengkapan organ otak memuat kurang lebih 100-200 miliar neuron atau sel saraf, ${ }^{30}$ hal tersebut menjadi wajar jika orang tua mengaktualisasikan potensi yang tinggi tersebut untuk anak. ${ }^{31}$ Namun dari 100-200 tersebut para peneliti mengemukakan hanya $5 \%$ saja yang teraktualisasi. ${ }^{32}$ Triliyunan sel yang ada dalam otak manusia mengabarkan betapa besar dan tingginya potensi manusia dalam memori akal dan otaknya. ${ }^{33}$

Pengasuhan melalui bimbingan pada anak usia pra sekolah hendaknya mengembangkan kecerdasan dan kesucian akalnya. Penelitian di bidang neuro science (ilmu tentang syaraf) menemukan bahwa kecerdasan sangat dipengaruhi oleh banyaknya sel syaraf otak, hubungan antar sel syaraf otak, dan keseimbangan karena otak kanan dan otak kiri. Pada saat lahir sel syaraf otak sudah terbentuk semua yang banyaknya mencapai 100-200 miliar, di mana setiap sel dapat membuat hubungan dengan 20.000 sel syaraf otak lainnya, atau dengan kata lain membentuk kombinasi 100 miliar $\times$ 20.000. Berdasarkan hal tersebut, usia pra sekolah (0-8 tahun) merupakan usia yang sangat kritis bagi pengembangan kecerdasan anak, sehingga masa keemasan ini harus dioptimalkan dan dimanfaatkan sungguh-sungguh dengan menstimulasinya secara baik. ${ }^{34}$

\footnotetext{
${ }^{29}$ Suryana, Dadan. (t.th). Hakikat Anak Usia Dini, Dasar-dasar Pendidikan TK. PAUD 4107/Modul 1, Kegiatan Belajar 1, hlm. 1.3, http://repository.ut.ac.id/4697/1/PAUD4107-M1.pdf, diakses 11 Juli 2019.

${ }^{30}$ Conny, Semiawan. (2013). Landasan Pembelajaran dalam Perkembangan Manusia. Jakarta: Pusat Pengembangan Kemampuan Manusia (CHCD), hlm. 11

${ }^{31}$ Conny, Semiawan. (2013). Landasan Pembelajaran dalam Perkembangan Manusia, hlm. 12; lihat juga Suryana, Dadan. (t.th). Hakikat Anak Usia Dini, hlm. 1.3

${ }^{32}$ Conny, Semiawan. (2013). Landasan Pembelajaran dalam Perkembangan Manusia, hlm. 13

33 Jensen, E. (2015). Brain Based Learning (Pembelajaran Berbasis Kemampuan Otak). Terjemahan. Jakarta: Pustaka Pelajar, hlm. 19-20

${ }^{34}$ Suryana, Dadan. (t.th). Hakikat Anak Usia Dini, hlm. 1.3-1.4
} 
Anak usia pra sekolah memiliki batasan usia tertentu, karakteristik yang unik, dan berada pada suatu proses perkembangan yang sangat pesat dan fundamental bagi kehidupan berikutnya. Selama ini orang dewasa mengidentikkan anak usia pra sekolah sebagai orang dewasa mini, masih polos dan belum bisa berbuat apa-apa karena belum mampu berpikir. Pandangan ini berdampak pada pola perlakuan yang diberikan pada anak, antara lain sering memperlakukan anak sebagaimana orang dewasa. Saat mendidik atau membimbing anak dipaksa mengikuti pola pikir dan aturan orang dewasa. Namun, seiring dengan berkembangnya ilmu pengetahuan dan banyaknya studi tentang anak usia pra sekolah, orang dewasa semakin memahami bahwa anak usia pra sekolah bukanlah orang dewasa mini, dan berbeda dengan orang dewasa. ${ }^{35}$

NAEYC salah satu asosiasi para pendidik anak yang berpusat di Amerika, telah mendefinisikan bahwa rentang usia anak pra sekolah berdasarkan hasil penelitian psikologi perkembangan anak bahwa ada pola umum yang dapat diprediksi berkaitan dengan perkembangan selama 8 tahun pertama usia anak. NAEYC membagi rentang usia anak pra sekolah menjadi 0-3 tahun, 3-5 tahun, dan 6-8 tahun. NAEYC mengisyaratkan bahwa anak usia pra sekolah merupakan individu yang unik, memiliki pola pertumbuhan dan perkembangan fisik, kognitif, sosio-emosional, kreativitas, bahasa dan komunikasi yang khusus sesuai dengan tahapan yang sedang dilalui oleh anak. ${ }^{36}$

Para pakar pendidikan anak usia pra sekolah berpendapat bahwa anak itu dibagi atas lima kelompok: 1). Usia 0-1 tahun disebut bayi, 2). Usia 1-3 tahun disebut anak baru berjalan, 3). Usia 3-4 tahun disebut usai pra sekolah, 4). Usia 5-6 tahun disebut usia sekolah dasar awal, 5). Usia 7-8 tahun disebut usia sekolah dasar lanjutan. Pakar lain mengatakan, berdasarkan penelitian perkembangan motorik halus, motorik kasar, sosial, dan kognitif serta perkembangan perilaku bermain dan minat permainan, maka enam tahap perkembangan anak usia pra sekolah, yaitu; 1). Young infants (baru lahir sampai 6 bulan), 2). Older infants (usia 7 bulan hingga 12 bulan), 3). Young toddlers (usia satu tahun), 4). Older toddlers (usia 2 tahun), 5). Pra sekolah 
dan kindergarten (usia 3 sampai 5 tahun), 6). Anak sekolah dasar kelas rendah atau primary school (usia 6 hingga 8 tahun). ${ }^{37}$

Menurut undang-undang nomor 20 tahun 2003 tentang Sisdiknas, anak usia pra sekolah adalah anak dari bayi baru lahir sampai 5 atau 6 tahun $(0-6) .^{38}$

\section{Pendidikan Anak Usia Pra Sekolah dalam Islam}

Pendidikan adalah untuk menjaga perkembangan dan pertumbuhannya agar sesuai dengan syariat Islam. Maka orang tua mesti menanamkan pendidikan dalam usia perkembangan dan pertumbuhan (usia pra sekolah) sedari lahir sampai usia sekolah (6 tahun). Dalam ilmu pendidikan yang di utarakan Dadan Suryana dalam modul pembelajaran anak usia dini atau taman kanak-kanak, beliau mengutip dari Direktorat PAUD tahun 2008 menyebutkan bahwa, usia pra sekolah orang tua harus menjaga dan memelihara perkembangannya.

Pokok pendidikan anak dalam Islam ialah pendidikan agama dan moral. Pada tatanan ini caranya dengan mendengarkan atau diperdengarkan, baik dengan dibacakan atau diperdengarkan lewat audio hal-hal yang baik bernuansa keagamaan dan keakhlakul karimahan.

Anak adalah manusia kecil yang memiliki potensi yang masih harus dikembangkan. Pada umumnya anak selalu memiliki tabiat dan karakter tersendiri, tidak akan sama dari kecil sampai dewasa. Anak-anak terkesan selalu aktif, dinamis, antusias dan selalu ingin tahu sesuatu yang dlihat, diperhatikan dan didengarkan, tidak merasa bosan bertanya dan bertanya, pada masa ini anak sebenarnya sedang belajar. ${ }^{39}$ Dalam pertumbuhannya terkadang anak berperangai egosi, rasa ingin tahu, terkadang anak terlihat unik, lucu, anak memiliki masa fokus yang sekejap, namun hal itu keadaan yang sangat berpotensi dalam pembelajaran anak usia pra sekolah. ${ }^{40}$

Usia pra sekolah bagi anak merupakan kehidupan yang harus dijalani sebagai proses pengembangan karakter yang fundamental bagi kesuksesan anak di masa akan

\footnotetext{
${ }^{37}$ Suryana, Dadan. (t.th). Hakikat Anak Usia Dini, hlm. 1.6 hlm. 4

${ }^{38}$ Lembaran Negara. (2003). Undang-undang Sistem pendidikan Nasional. Jakarta: Sisdiknas, 1-33,

${ }^{39}$ Hayati, Nur Rohmah. (2016). "Pendidikan Pra Sekolah (Pendidikan Anak Usia Dini) dalam Islam”. aȘ-Ṣibyan, Vol.1, No.1, 72-82, hlm. 74

${ }^{40}$ Sujiono, Yuliani Nurani. (2013). Konsep Dasar Pendidikan Anak Usia Dini. Jakarta: PT. Indeks, hlm. 6.
} 
datang, usia tersebut antara 0-8 tahun. ${ }^{41}$ Usia ini masa proses pertumbuhan dalam berbagai aspek secara cepat dan rentan dengan perlakuan yang kurang baik, hal itu dapat menghambat pertumbuhan karakter baiknya. ${ }^{42}$ Oleh karenanya orang tua harus aktif mendidik anak sejak baru lahir sampai lamanya kelangsungan hidup sepanjang hayat. $^{43}$

\section{Manajemen Pendidikan Islam Anak-Anak Pra Sekolah Berbasis Al-Qur’an}

Ilmu manajemen umum memaknai manajemen adalah suatu perencanaan yang terorganisir dengan baik dan selalu dievaluasi melalui control yang ketat, maka akan menghasilkan output yang di inginkan. Menurut Ibnu Sina sebagaimana dikutip Lis Yulianti, dalam bukunya Ibnu sina yang berjudul: "As-Siyasah, ide-ide yang cemerlang dalam mendidik anak". Beliau mengatakan ketika mendidik anak, maka pertama kali ajarkan al-Qur'an, agar fisik dan mentalnya lebih ready untuk belajar. ${ }^{44}$ Maknanya pendidikan anak usia pra sekolah yang paling penting adalah al-Qur'an. Oleh karenanya menurut penulis manajemen pendidikan Islam anak usia pra sekolah yang berbasis al-Qur'an adalah suatu kemutlakan. Lalu bagaimana sistematika manajemen yang berbasis al-Qur'an untuk anak pra sekolah, menurut penulis sebagai berikut:

\section{Planning/Perencanaan}

Orang tua sebagai manajer dan juga pelaksana pendidikan anak usia pra sekolah, jika menginginkan anaknya menjadi anak yang Qur'ani mesti membuat planning perencanaan bagaimana anak hafal dan pandai baca al-Qur'an. Sesuai dengan generik perkembangan menurut Dirjen Direktorat PAUD menyatakan, bahwa orang tua harus banyak membuat rencana bagaimana anak selalu bisa mendengar dan diperdengarkan ayat- ayat wahyu al-Qur'an, sehingga tiada hari dan waktu yang didengar oleh anak usia pra sekolah kecuali lantunan ayat suci al-Qur'an,

\footnotetext{
${ }^{41}$ Hayati, Nur Rohmah. (2016). "Pendidikan Pra Sekolah", hlm. 74

${ }^{42}$ Sujiono, Yuliani Nurani. (2013). Konsep Dasar Pendidikan Anak Usia Dini, hlm. 6-7

${ }^{43}$ Budiyanto, Mangun. (2015). Ilmu Pendidikan Islam. Yogyakarta: Griya Santri, hlm. 109.

${ }^{44}$ Siregar, Lis Yulianti Syafrida. (t.th). "Pendidikan Anak Usia Dini dalam Perspektif Pendidikan Islam". Prosiding Interdisciplinary Postgraduate Student Conference 1 st Program Pascasarjana Universitas Muhammadiyah Yogyakarta (PPs UMY), 130-139, hlm. 137
} 
hal ini akan larut dalam jiwa dan terbiasa menjadikan hal itu sebagai kebutuhan, jika ini diaplikasikan akan mendatangkan hal yang baik.

\section{Organizing/Pengkelompokan}

Setelah orang tua berencana ingin memperdengarkan ayat-ayat al-Qur'an untuk anak-anaknya dirumah yang berusia pra sekolah, mesti orang tua mengelompokkan dari ayat-ayat al-Qur'an tersebut, mana yang lebih diutamakan sesuai dengan konsep keinginan orang tua terhadap anaknya yang berkaitan dengan al-Qur'an. Jika ingin menjadikan anak tersebut hafidz dan hafidzah, menurut sebahagian ahli, orang tua harus mengelompokkan masing-masing dari 30 juz alQura'an menjadi 30 bahagian, sehingga kesan kepada anak-anak pra sekolah yang selalu mendengar ayat-ayat tersebut akan mudah mengingat memorinya ketika sudah mumayiz.

\section{Actuating/Pelaksanaan}

Pengelompokan 30 juz menjadi 30 kelompok, maka akan di aplikasikan dengan cara seperti apa?. Jika orang tua menghendaki anaknya menjadi penghafal alQur'an, maka selanjutnya orang tua harus memperdengarkan dengan cara dibacakan atau diperdengarkan dengan audio al-Qur'an setiap seminggu satu juz setiap, artinya setiap hari selama seminggu bibacakan diperdengarkan satu juz secara maraton, atau dalam jangka satu bulan satu juz. Jika seminggu satu juz, maka 30 juz menjadi 30 minggu atau 7, 5 bulan atau 7 bulan setengah, anak telah mendengar berulang-ulang ayat- al-Qura'an 30 juz. Jika satu juz sebulan berarti 30 juz 30 bulan atau 2,5 tahun atau 2 tahun setengah anak sudah mendengar al-Qur'an berkali-kali sebanyak 30 juz.

\section{Controlling/Pengawasan}

Jika pengelompokan sudah dilakukan dan pelaksanaan sedang berjalan, maka orang tua harus mengontrol secara rutin apakah dalam satu hari tersebut anak sudah dibacakan atau diperdengarkan ayat-ayat al-Qur'an sebanyak satu juz. Jika belum mesti harus segera dilakukan, jangan sampai terluput satu haripun anak dari mendengar dan diperdengarkan ayat al-Qur'an yang satu juz tersebut. control dalam hal ini sangat penting, jika pengawasannya kurang mengakibatkan kurang maksimal 
anak mendengar ayat-ayat al-Qur'an satu juz tersebut, jika nantinya hafal al-Qur'an maka hafalan anak akan mudah hilang atau terlangkap-langkap atau loncat-loncat tidak sesuai urutan dalam al-Qur'an. Juga anak di awasi dari mendengarkan hal-hal yang lian selaian al-Qur'an berlebihan, hal ini juga akan mengacaukan memori anak dan hafalannya.

\section{Evaluating/Evaluasi}

Keinginan orang tua mempunyai anak yang hafal al-Qur'an mungkin dambaan semua orang. Namun setelah dilakukan manajemen Qur'ani dalam pendidikan rumah tangga anak usia pra sekolah, dari mulai diperdengarkan secara maraton dan di awasi pelaksanaannya, tentunya orang tua ingin melihat sejauh mana anak-anaknya memahami al-Qur'an yang dibacakan dan diperdengarkan. Maka langkah berikutnya adalah dievaluasi, sejauh mana sudah keberhasilannya. Hal in dapat di uji dengan dua cara. Pertama, tanyalah kepada anak-anak usia pra sekolah tentang bacaan yang dia dengar selama ini, uji dan ajarkan dengan perlahan bacaan ayat-ayat tersebut, jika anak mudah menyabungnya walaupun dengan terbatah-batah atau igauan, berarti sudah berhasil anak secara sederhana memahami apa yang dia dengar dan diperdengarkan dari ayat al-Qur'an. Kedua, jika dalam sehari biasa dibacakan atau diperdengarkan ayat al-Qur'an misalnya tiga kali, lalu dia baru mendengar dua kali, sementara ia merasa ada yang hilang dan kurang, atau jika harihari diperdengarkan audio ayat-ayat al-Qur'an, lalu dimatikan, tapi anak merasa kesepian atau kegundahan atau protes lainnya, hal ini juga menjadi bukti bahagian dari keberhasilan mendidik anak usia pra sekolah dengan basis Qur'ani.

Dari empat teori manajemen umum di atas, maka jika berjalan dengan baik sesuai rencana ini akan melahirkan anak-anak generasi muda yang hafal, paham, pandai dan gemar mempelajari al-Qur'an, dengannya bagi orang tua yang berkeinginan anak-anaknya menjadi ahli qur'an, maka seharusnya mendidik anak di bawah usia sekolah dengan konsep yang berbasis al-Qura'an. Anak jiwanya suci dan bersih sebagai fitrah anak-anak, maka bila kesuciannya dimanfaatkan untuk hal yang bernuansa kitab suci dari wahyu Allah yang maha suci, InsyaAllah akan muncullah generasi yang Qur'ani di masa yang akan datang. Jikalau anak hafal al-Qur'an, maka 
kedua orang tuanya nantinya di akhirat akan mendapat syafaat al-Qur'an dari hafalan al-Qur'an anaknya.

\section{KESIMPULAN}

Al-Qur'an kitab yang sangat sempurna, jika diteliti didalamnya kata "anak" memilki beberapa varian istilah, misalnya zurriyah, ibn, walad, athfal, shabiy, aqrab, asbath, ghulam, thifl, nasl, rabaib, dan ad'iya'akum. Perbedaan istilah dan makna yang terkandung dalam istilah tersebut merupakan bukti bahwa Al-Qur'an sangat peduli terhadap keberadaan anak sekaligus bagaimana pola pendidikan yang efektif diberlakukan. Ibnu Sina berpendapat bahwa awal mula mendidik anak adalah dengan mengajarkan al-Qur'an, sebagai bentuk persiapan mental dan fisik untuk menempuh pendidikan yang lebih insentif. Hal ini menjadi dasar perlunya manajemen pendidikan anak berbasis Qur'ani.

Manajemen adalah suatu perencanaan yang terorganisir dengan baik dan selalu dievaluasi melalui control yang ketat, maka akan menghasilkan tujuan yang di inginkan. Dalam hal manajemen pendidikan pra sekolah berbasis al-Qur'an, maka diperuntukkan kepada orang tua agar merencanakan untuk anaknya selalu mendengarkan lantunan ayat suci al-Qur'an. Kemudian mengelompokkan dalam memperdengarkan ayat-ayat tersebut dalam bentuk per juz al-Qur'an dalam satu bulan. Selanjutnya orang tua mengevaluasi anak yang sudah diperdengarkan alQur'an, jika diberhentikan sejenak lantunan tersebut, apa yang akan terjadi reaksi anak. Jika menangis, berarti ruh al-Qur'an sudah masuk dalam hati dan jiwanya. Keadaan tersebut berlaku sampai 30 juz, maka anak selama 30 bulan sudah mendengarkan dan merekam 30 juz ayat-ayat al-Qur'an, insyaAllah umur pra sekolah anak sudah banyak hafal dan akan cerdas dengan wasilah ayat al-Qur'an. Inilah manajemen berbasis Qur'ani yang melahirkan anak-anak yang cinta dan gemar baca al-Qur'an serta hafidz al-Qur'an. 


\section{DAFTAR PUSTAKA}

Abdul Baqi, Muhammad Fuad. (1990). al-Mu'jam al-Mufahras li Alfaz, Al-Qur'an al-Karim. Beirut: Dar al-Fikr li at-Tiba'ah wa an-Nasyr wa at-Tauzu'.

Arif, Armai. (2013). Pengantar Ilmu dan Metodologi Pendidikan Islam. Jakarta: Ciputat Pers.

Budiyanto, Mangun. (2015). Ilmu Pendidikan Islam. Yogyakarta: Griya Santri.

Conny, Semiawan. (2013). Landasan Pembelajaran dalam Perkembangan Manusia. Jakarta: Pusat Pengembangan Kemampuan Manusia (CHCD).

Departemen Agama RI. (2015). Al-Qur'an dan Terjemahanya. Semarang: Toha Putra.

Dirjen Pendidikan Luar Sekolah Direktorat PAUD. (2015). Bekal Mendidik Anak Usia Dini. Jakarta: Dirjen pendidikan Luar Sekolah.

Fadhilah, Muhammad. (2015). Desain Pembelajaran Paud. Jogyakarta: Ar-Ruzz media.

Hasan, Maimunah. (2014). PAUD. Jakarta: Diva Press.

Hayati, Nur Rohmah. (2016). "Pendidikan Pra Sekolah (Pendidikan Anak Usia Dini) dalam Islam”. aȘ-Ṣibyan, Vol.1, No.1, 72-82.

Ilham Senjari. (2017). " Tanggung jawab orang tua terhadap pendidikan anak dalam persepektif hadis". Surakarta: IAIN Surakarta Fakultas Ilmu Tarbiyah dan Keguruan.

Jensen, E. (2015). Brain Based Learning (Pembelajaran Berbasis Kemampuan Otak). Terjemahan. Jakarta: Pustaka Pelajar.

Lembaran Negara. (2003). Undang-undang sisntem pendidikan nasional. Jakarta: Sisdiknas, 1-33.

Mansur. (2013). Pendidikan anak usia dini dalam Islam. Yogyakarta: Pustaka Pelajar.

Moeslichatoen. (2014). Metode Pengajaran di Taman Kanak-kanak. Jakarta: PT Rineka Cipta.

Mulyasa. (2016). Manajemen PAUD. Bandung: PT Remaja Rosdakarya.

Munawwir, Ahmad Warson. (1997). Kamus al-Munawwir. Surabaya: Pustaka Progresif.

Santi Awaliyah. (2008). "Konsep Anak dalam Al-Qur'an dan Implikasinya Terhadap Pendidikan Islam dalam Keluarga”. Jogjakarta: Fakultas Tarbiyah UIN Sunan Kalijaga.

Siregar, Lis Yulianti Syafrida. (t.th). "Pendidikan Anak Usia Dini dalam Perspektif Pendidikan Islam". Prosiding Interdisciplinary Postgraduate Student Conference 1 st Program Pascasarjana Universitas Muhammadiyah Yogyakarta (PPs UMY), 130-139.

Sujiono, Yuliani Nurani. (2013). Konsep Dasar Pendidikan Anak Usia Dini. Jakarta: PT. Indeks.

Suryana, Dadan. (t.th). Hakikat Anak Usia Dini, Dasar-dasar Pendidikan TK. PAUD 4107/Modul 1, Kegiatan Belajar 1, http:/ / repository.ut.ac.id/4697/1/PAUD4107-M1.pdf, diakses 11 Juli 2019.

Zulfitria. (2016). "Pembelajaran Tahfidz al-Qur'an dalam pendidikan karakter anak usia dini (PAUD)". Darul Ilmi, Pendidikan Islam Anak Usia Dini, Volume 1 No 2, 35-55. 